\title{
ANALISIS STRUCTURE, CONDUCT, PERFOMANCE (SCP) USAH MIKRO KECIL MENENGAH (UMKM) KERUPUK SAGU DIKECAMATAN KUANTAN TENGAH
}

\author{
Yoga Rinandi'), Rahmita B Ningsih ${ }^{2)}$, Hj. Rita Yani Iyan ${ }^{3)}$ \\ 1) Mahasiswa Jurusan Ilmu Ekonomi, Fakultas Ekonomi Dan Bisnis, Universitas Riau \\ 2) Dosen Jurusan Ilmu Ekonomi, Fakultas Ekonomi Dan Bisnis, Universitas Riau
}

\begin{abstract}
This study aims to determine the market structure, performance and behavior of the sago cracker industry in central Kuantan District. This research is quantitative descriptive. The population of this study were all sago cracker industry players in central Kuantan District. The non-probability sampling method chosen is saturated sampling by taking the entire population as a sample. The analytical technique used in this research is scp (structure, conduct, performance). Based on the results of the research, the market structure formed in the sago cracker industry in Kuantan Tengah district is a monopolistic competition market. this is based on the calculation of cr4 obtained results of $51.81 \%$ included in $40<\mathrm{cr} 4<60$ so that it is classified as middle to lower category. Where the highest market share is $14.92 \%$ and the lowest is $4.21 \%$. The calculation of the minimum efficiency scale (mes) is to determine the magnitude of market barriers for new players in the sago cracker industry in the district of Kuantan Tengah. The mes value obtained is $14.92 \%$ which allows new players to be relatively easy to enter the market. This requires that every company in the market must be ready to compete with new players who will threaten the market share of the old company. Based on descriptive research conducted by asking direct questions to sago cracker business actors in Kuantan Tengah district, there are three industrial behaviors, namely pricing, product and promotion strategies. Based on the results of the study, it was found that the average price cost margin of all sago cracker industry players in the Kuantan Tengah sub-district was $31.11 \%$, the highest pcm was $45 \%$ with a total share of $9.95 \%$, while the company with the highest market share was $14.92 \%$ the value of the pcm that is obtained is $30 \%$.
\end{abstract}

\section{Keywords: Structure, Conduct, Perfomance}

ABSTRAK : Penelitian ini bertujuan mengetahui struktur pasar, kinerja dan perilaku industri kerupuk sagu di Kecamatan Kuantan Tengah. Penelitian ini merupakan penelitian deskriptif kuantitatif. Populasi penelitian ini adalah seluruh pelaku industri kerupuk sagu di Kecamatan Kuantan Tengah. Metode pengambilan nonprobality sampling yang dipilih yaitu sampling jenuh dengan mengambil selrurh populasi sebagai sampel. Teknik analisis yang digunakan dalam penelitian ini adalah scp (structure, conduct, performance). Berdasarkan hasil penelitian struktur pasar yang terbentuk dalam industri kerupuk sagu yang berada di Kecamatan Kuantan Tengah adalah pasar persaingan monopolistik . hal ini berdasarkan dari perhitungan cr4 yang diperoleh hasil sebesar $51,81 \%$ termasuk dalam $40<\mathrm{cr} 4<60$ sehingga tergolong kategori menengah kebawah. Dimana pangsa pasar tertinggi adalah sebesar $14,92 \%$ dan terendah sebesar 4,21\%.perhitungan terhadap skala minimum efisiensi (mes) untuk mengetahui besarnya hambatan pasar bagi pemain baru pada industri kerupuk sagu di kecamatan kuantan tengah. Nilai mes yang didapat sebesar 14,92\% yang memungkinkan pemain baru tergolong mudah untuk masuk kedalam pasar. Hal ini mengharuskan setiap perusahaan yang berada di dalam pasar harus siap bersaing dengan pemain baru yang akan mengancam pangsa pasar dari perusahan lama. Berdasar penelitian deskriptif yang dilakukan dengan cara memberikan pertanyaan langsung kepada pelaku usaha kerupuk sagu yang ada di Kecamatan Kuantan Tengah ada tiga perilaku industri yakni strategi 
harga, produk dan promosi. Berdasarkan hasil penelitian, di peroleh rata-rata price cost margin seluruh pelaku industri kerupuk sagu di Kecamatan Kuantan Tengah sebesar 31,11 \%, pcm tertinggi senilai $45 \%$ dengan jumlah pangsa sebesar $9,95 \%$, sedangkan perusahaan dengan pangsa pasar tertinggi $14,92 \%$ nilai dari pem yang di dapatkan sebesar $30 \%$.

Kata Kunci : Structure, Conduct, Perfomance

\section{A. PENDAhuluan}

Sektor Perindustrian merupakan salah satu sektor yang sangat berpotensi untuk meningkatkan perekonomian suatu Negara. Pertumbuhan ekonomi berarti perkembangan kegiatan dalam perekonomian yang menyebabkan barang dan jasa yang diproduksi masyarakat bertambah dan kemakmuran masyarakat meningkat.Salah satu daerah yang mempunyai perkembangan industri kecil adalah Kecamatan Kuantan Tengah, Kecamatan Kuantan Tengahmerupakan ibukota dari Kabupaten Kuantan Singingi. Di setiap daerahtentunya memiliki industri kecil yang mungkin menjadi tempat bergantungnya perekonomian masyarakat didaerah tersebut, begitu juga yang terjadi di Kecamatan Kuantan Tengah, KabupatenKuantan Singingi.

Diantara banyaknya sektor industri salah satunya adalahindustri pangan kerupuk sagu mempunyaiperkembangan yang cukup baik terutama yang berada di Kecamatan KuantanTengah, Kabupaten Kuantan Singingi. Perkembangan usaha kecil mikro menengah (UMKM) dapat dilihat dari tabel berikut.

Tabel 1. Perkembangan Usaha Kecil Mikro Menengah (UMKM) Tahun 2008-2018 Kabupaten Kuantan Singingi.

\begin{tabular}{|c|c|c|c|}
\hline No & Tahun & $\begin{array}{c}\text { UMKM } \\
\text { (Unit) }\end{array}$ & Tenaga Kerja (Orang) \\
\hline 1 & 2008 & 7 & 18 \\
\hline 2 & 2009 & 6 & 15 \\
\hline 4 & 2010 & 6 & 15 \\
\hline 4 & 2011 & 8 & 19 \\
\hline 5 & 2012 & 10 & 25 \\
\hline 6 & 2013 & 10 & 32 \\
\hline 7 & 2014 & 10 & 44 \\
\hline 8 & 2015 & 11 & 50 \\
\hline 9 & 2016 & 12 & 63 \\
\hline 10 & 2017 & 17 & 63 \\
\hline 11 & 2018 & 17 & $S i n g i n g$ \\
\hline
\end{tabular}

Sumber : Dinas Koperasi Perdangan Dan Perindustrian Kabupaten Kuantan Singingi2020

Berdasarkan data pada tabel 1 dapat dilihat bahwa perkembangan usaha mikro kecil menengah di Kabupaten kuantan singingi dari tahun 2008 hingga 2018 mengalami peningkatan. Pada tahun 2008 jumlah UMKM 7 unit, mempunyai anggota 18. Pada tahun 2009 dan 2010 jumlah UMKM menurun. Pada tahun 2011 jumlah UMKM kembali naik menjadi 8 unit, memiliki anggota 19 orang.

Perkembangan UMKM pada tahun 2012 sampai 2014 jumlah UMKM tidak mengalami perubahan, akan tetapi jumlah anggotanya terus bertambahdari tahun 2012 sampa tahun 2014. Sedangkan pada tahun 2015 sampai 2017 selalu mengalami peningkatan, akan tetapi pada 2018 jumlahnya tetap.Salah satu sektor usaha mikro kecil dan menengah yang ada di Kecamatan Kuantan Tengah adalah industri Pengolahan pangan yakni usaha mikro kecil dan menengah kerupuk sagu. Industri ini merupakan usaha turun-temurunyang sudah ada di Kota Taluk Kuantan sejak lama menurut salah seorang pengusaha yakni Bujang Laisar, industri ini sudah ada sejak tahun 1987 dan masih ada sampai saat sekarang ini.

Berikut data industri pengolahan pangan kerupuk saguyang ada di Kecamatan Kuantan Tengah. 
Tabel 2. Data Usaha Mikro Kecil Dan Menengah (UMKM) KerupukSaguDi Kecamatan Kuantan Tengah Di Tahun 2018

\begin{tabular}{|c|c|c|c|}
\hline No & Nama Perusahaan & Nilai Investasi & TenagaKerja \\
\hline 1 & Air mata & Rp 10.000.000 & 3 \\
\hline 2 & Nyonyok & Rp 5.500.000 & 3 \\
\hline 3 & Bujang laisar & Rp 5.000.000 & 3 \\
\hline 4 & Noprianto & Rp 2.000.000 & 3 \\
\hline 5 & Rostina & Rp 2.000.000 & 1 \\
\hline 6 & Linda & Rp 5.000.000 & 2 \\
\hline 7 & Fitrianah & Rp 2.000.000 & 2 \\
\hline 8 & Basnah riati & Rp 2.000.000 & 2 \\
\hline 9 & Asneti & Rp 3.000.000 & 2 \\
\hline 10 & Widia jaya & Rp 1.000.000 & $\mathbf{2 9}$ \\
\hline 11 & Yusni & Rp 2.000.000 & Rp 39.500.000 \\
\hline
\end{tabular}

Sumber : Dinas Koperasi Perdagangan Dan Perindustrian Kuantan Singingi 2020

Dari tabel diatas dapat kita lihat terdapat ada 11 perusahaan kerupuk sagu yang bersaing di dalam pasaruntuk memperebutkan pangsapasar yang ada di Kota Taluk Kuantan. Semakin tinggi pangsa pasar, maka semakin tinggi kekuatan pasar yang dimiliki perusahaan tersebut atau perusahaan tersebut dikatakan monopoli penuh. Bila pangsa pasar yang dimiliki oleh perusahaan kecil, makaperusahaan tersebut mempunyai kekuatan monopoli pasar yang kecil. Dengan jumlah 11 perusahaan kerupuk sagu yang ada di Kota Taluk Kuantan tentunya kita dapat melihat konsentrasi pasar dari beberapa perusahaan yang memiliki pangsa pasar cukup tinggi.

Konsentrasi pasar merupakan penggabungan pangsa pasar bebera perusahaan yang memiliki pangsa pasar yang besar di dalam pasar. Menurut Lipczynski (2005), konsentrasi pasar menunjukan seberapa penting peran perusahaan terbesar (biasanya 4 sampai 8 perusahaan) dalam suatu pasar atau industri yang akan menunjukan bagaimana struktur pasar maupun jenis pasar yang ada dalam suatu industri.

Besarnya jumlah pangsa pasar juga dapat mempengaruhi hambatan masuk pasar. Hambatan masuk pasar merupakan segala sesuatu yang menghalangi atau menghambatan perusahaan baru yang ingin masuk ke dalam pasar. Seperti halnya di dalam industri kerupuk sagu yang ada di Kota Taluk Kuantan jika hambantan masuk pasar tinggi maka akan berat bagi perusahaan baru untuk masuk kedalam pasar, sehingga dapat membuat pesaing perusahaan yang sudah ada di dalam pasar tidak bertambah. Perusahaan yang menguasai pasar di industri kerupuk sagu ini tentunya dapat mengandalikan pasar dan akan menunjukan perilaku dari perusahaantersebut.

Perilaku industri menunjukan bagaimana individu perusahaan berperilaku di dalam pasar,misalnya dalam menentukan harga, promosi maupun kolusi dalam tujuan untukmendapatkan atau meningkatkan pangsa pasar.Perilaku suatu perusahaan sangat menuntukan bagaimana perkembangan suatu perusahaan, apabila perusahaan tidak bijak dalam pengambilan keputusan tentunya akan berdampak buruk bagi perusahaan itu sendiri. Menurut salah satu pengusaha yang berada di desa pulau banjar kari, Kecamatan Kuantan Tengah mereka menentukan harga dengan cara mengukuti perusahaan lainnya yang dianggap sebagai patokan ataupun biasanya disebut leader dan rata-rata produkkerupuk sagu sudah memiliki label disetiap kemasannya yang bertujuan untuk promosi agar perusahaanyalebih dikenal oleh konsumennya.

Tepat atau tidaknyakeputusan suatu perusahaan dapat dilihat dari kinerja suatu perusahaan. Kinerja industri merupakan keuntungan dan kesejateraan sosial yang di hasilkan suatu industri. Keuntungan industri merupakan selisih antara pendapatan total dan biaya total perusahanperusahaan yang ada di dalam industri. Seperi misalnya perusahan-perusahaan yang ada di dalam pasar industri kerupuk sagu di Kota Taluk Kuantan, tentunya setiap perusahaan yanga ada di pasar akan memiliki kinerja yang berbeda-beda tergantung bagaimana cara mereka dalam berperilaku ataupun mengambil keputusan. 
Industri kerupuk sagu yang berada di Kabupaten Kuantan Singingi merupakan sektor industripengolahan yang sudah lama diberdayakan oleh masyarakat Kuansing khusunya di Kota Taluk Kuantan, Kecamatan Kuantan Tengah dan juga ada yang menggantungkankehidupan perekonomiannya dengan menjadi pengusaha ataupun penjual kerupuk sagu.

Seiring berjalannya waktu tentunya setiap industry mengalami banyak permasalahan dan hambatan dalam mengambangkan usahanya sehingga perlu adanya masukan, edukasi maupun bantuan bagi setiap pengusaha kerupuk sagu yang ada di Kecamatan Kuantan Tengah, baik secara pengolahan, pengemasan dan juga pemasaran. Dengan adanya edukasi ataupun bantuan baik berupa barang ataupun pengetahuan di harapkan dapat memajukan industri kerupuk sagu dan berdampak positif bagi perekonomian masyarakat yang berperan sebagai pengusahaan kerupuk sagu.

Berdasarkan latar belakang di atas, maka saya sebagai peneliti tertatik untuk meneliti bagaimanakondisi struktur, perilaku dan kinerjapasar industri kerupuk sagu yang adadi kecamatan kuantan tengah dengan judul "ANALISIS STRUCTURE, CONDUCT, PERFOMANCE(SCP) USAHA MIKRO KECIL MENENGAH (UMKM) KERUPUK SAGU DI KECAMATAN KUANTANTENGAH"

\section{Rumusan Masalah}

Berdasarkan penjelasan dari latar belakang dan keadaan usaha mikro kecil menengah kerupuk sagu di Kota Taluk Kuantan, maka rumusan masalah dari penelitian ini adalah :

1. Bagaimanakah kondisi Struktur Pasar Industri Kerupuk Sagu yang di Kecamatan Kuantan Tengah?

2. Bagaimanakah Perilaku IndustriKerupuk Sagu yang di KecamatanKuantan Tengah ?

3. Bagaimanakah Kinerja Industri Kerupuk Sagu yang di KecamatanKuantan Tengah?

\section{Tujuan Penelitian}

Sesuai dengan rumusan masalah yang saya kemukakan sebagai peneliti maka, tujuan dan manfaat penelitian adalah :

1. Untuk mengetahui bagaimana kondisi struktur pasar industri kerupuk sagu yang di Kecamatan Kuantan Tengah.

2. Untuk mengetahui kinerja industri kerupuk sagu yang di Kecamatan Kuantan Tengah.

3. ntuk mengetahui perilakuindustri kerupuk sagu yang di Kecamatan Kuantan Tengah.

\section{Manfaat Penelitian}

Berdasarkanrumusan masalah dan hasil dari penilitian ini, maka diharapkan penilitan ini dapat digunakan untuk :

1. Dari hasil penelitian ini diharapkan dapat membantu para pengusaha yang berada dalam industri kerupuk sagu diKecamatan Kuantan Tengahdalam mengambangkanusahanya.

2. Dengan adanya penelitian ini di harapkan penelitian ini menjadiwadah saya untuk menuangkan ilmu pengetahuan yang saya peroleh selama mengikuti perkuliahan pada Jurusan Ilmu Ekonomi Program Studi Ekonomi Pembangunan Fakultas Ekonomi Dan Bisnis, UniversitasRiau.

3. Merupakan bahan masukan bagi pemerintah khususnya dinas koperasi perindustrian dan perdagangan Kabupaten Kuantan Singingi dalam mengembangkan usaha industri kecil khususnya industri kerupuk sagu diKecamatanKuantan Tengah

4. Sebagai bahan informasi atau referensi bagi peneliti lain yang ingin meneliti lebih lanjut dalam aspek yang sama maupun aspek yang berhubungan.

\section{B. METODE PENELITIAN}




\section{Lokas Penelitian}

Lokasi penelitian di lakukan di Kecamatan Kuantan Tengah,dipilihnya Kecamatan Kuantan Tengah sebagai lokasi penelitian karena Kecamatan Kuantan Tengah memiliki pertumbuhan industri kecil yang cukup baik. Salah satu industri kecilnya adalah industri kerupuk sagu yang berada diKecamatan KuantanTengah,Kabupaten Kuantan Singingi.

\section{Populasi Dan Sampel}

Penentuan sampel dalam penelitian ini menggunakan nonprobality sampling, menurut sugiono (2005) nonprobality sampling adalah tehnik yang tidak memberi peluang yang sama bagi setiap unsur atau anggota populasi untuk dipilih menjadi sampel. Teknik nonprobality sampling yang dipilih yaitu sampling jenuh (sensus) yaitu metode penarikan sampel bila semua populasi dijadikan sampel. Hal ini sering terjadi apabila populasi kecil ataupun kurang dari 30 orang

\section{Jenis Dan Sumber Data}

Data yang digunakan dalampenelitian ini merupakan data primer dan data sekunder, yaitu:

a. Data Primer

Data primer adalah data yang diperoleh langsung dari subjek penelitian, dalam hal ini peneliti memperoleh data atau informasi yang diperlukan dalam penelitian. Dalam penelitian inimetode pengambilan data primer dilakukan dengan cara kuisioner.

b. Data Sekunder

Data sekunder adalah data yang berasal dari instansi atau dinas-dinas yang terkait langsungatau pun tidak langsung dalam penelitian ini, yaitu DinasKoperasi perdagangan dan perindustrian Kabupaten Kuantan Singingi.Data sekunder yang digunakan dalam penelitian ini dapat berupa dokumen-dokumen atau literatur-literatur dariinternet, jurnal, dan skripsi.

\section{Teknik Pengumpulan Data}

Di dalam pengumpulan data- data yang diperlukan, penulis menggunakan metode kualitatif dalam pengumpulan data, dengan cara kuisioner dan pencatatan langsung data yang diperlukan. Baik dari Dinas terkait maupun melakukan telaah beberapa literature seperti buku, jurnal, serta laporan- laporan ilmiah yang berhubungandengan objek penelitian

\section{Metode Analisis Data}

Metode analisis yang digunakan dalam penelitian ini adalah analisis deskriptif dan analisis kuantitatif. Metode kuantitatif yang digunakan adalah untuk meneliti struktur dan kinerja pasar, sedangkan untuk perilaku pasar khususnya penetapan harga dan promosi digunakan analisis deskriptif. Adapun analisis model matematis yang digunakan untuk meneliti perkembangan industri pangan kerupuk sagu di Kecamatan KuantanTengah, yakni :

\section{Analisis Struktur Pasar}

\section{a. Rasio Konsentrasi(Concentration Ratio)}

konsentrasi rasio merupakan jumlah pangsa pasar $\mathrm{N}$ perusahaan didalam suatu pasar terhadap total seluruh pangsa pasar perusahaan yang ada di dalam industri (Gwin,2000 dalam Lincolin,Stephanus,2014) yang dapat dirumuskan sebagai berikut:

$$
C R_{N}=S_{\mathrm{i}}+S_{\mathrm{i}}+S_{\mathrm{i}}+\cdots S_{N}
$$


Dimana :

$=$ rasio konsentrasi sebanyak $\mathrm{N}$ perusahaan

= pangsa pasar perusahaan i Pangsa pasar merupakan jumlah penjualan perusahaan i dibagi dengan total jumlah penjualan seluruh perusahaan yang ada di dalampasar, dapat dirumuskan sebagai berikut :

$$
S_{i}=\frac{\mathrm{xi}}{\mathrm{xtot}} \times 100 \%
$$

Dimana :

$\mathrm{I} \quad=$ pangsa pasar perusahaan $\mathrm{i}$

$\mathrm{Xi} \quad=$ jumlah penjualan

perusahaan i

Xtot $=$ total penjualan perusahaandi dalam pasar

\section{b. Indeks Hirschan-Herfindahi(IHH)}

IndeksHirschan-Herfindahi merupakan penyempurnaan dari rasio konsentrasi. IHH merupankanpejumlahan hasil kuadrat dari pangsapasar perusahaan yang ada didalamsuatu pasar (Lipczynki,2009Dalam Lincolin, Stephanus, 2014)

$$
\mathrm{IHH}=\sum_{i=1}^{N} S_{i}^{2}
$$

Dimana :

HHI $=$ IndeksHirschan-Herfindahi

$\mathrm{N} \quad=$ jumlah perusahaan didalam pasar

$\mathrm{i} \quad=$ pangsa pasar perusahaan $\mathrm{i}$

\section{c. Hambatan Masuk Pasar}

Hambatan masuk pasar dapat diukur dengan rasio skala produksi dengan skala produksi minimum untuk mencapai efesiensi perusahaan(Minimum Efficiency Scale/MES). MES merupakan uotput minimum yang dihasilkan perusahaan ketika perusahaan mencapai biaya produksirata-rata terendahnya.

$$
\text { MES }=\frac{\text { outputperusahaanterbesar }}{\text { outputtotal }} \times 100 \%
$$

\section{d. Analisis Perilaku Pasar}

Analisis perilaku industri dilakukan dengan analisis deskriptif pada masing-masing industri diamatimulai mengidentifikasi strategi produk, strategi harga dan strategi promosi yang kemudian peneliti dapat menentukan apakah perilaku industri tersebut sudah sesuai dengan kondisi pasar ataupun berlawanan dengan kondisi di dalam pasar industri kerupuk sagu yang ada dikecamatan kuantan tengah.

\section{e. Kinerja Industri}

Faktor ini diukurmenggunakan margin keuntungan yang disebut Price - Cost Margindan efisiensi . PCM merupakan indikatorr kemampuan perusahaan untuk meningkatkan harga diatas biaya produksi. PCM dapat dirumuskan sebagai berikut (Lipczynki, 2005dalam Wurryanto, 2011) 


$$
\mathrm{PCM}=\frac{\text { nilaitambah-upah }}{\text { nilaiuotput }} x 100
$$

Dimana :

PCM = keuntungan perusahaan

Nilai tambah $=$ nilai output - nilai input

Nilai output $=$ nilai penjualan.

\section{HASIL DAN PEMBAHASAN}

Dari hasil penelitian terhadap seluruh populasi yang mana sampelnya sebanyak 11 atau seluruh pelaku usaha mikro menengah kecil (umkm) kerupuk sagu di Kecamatan Kuantan Tengah yang masih aktif, maka di peroleh hasil yang di uraikan lebih jelas satu persatu sebagai berikut.

\section{Struktur Pasar}

Market Share (pangsa pasar) Industri Usaha Mikro Kecil Menengah (Umkm) Kerupuk Sagu Di Kecamatan Kuantan Tengah Pangsa Pasar adalah perbandingan antara nilai penjualan perusahaan yang di miliki sendiri dengan total seluruh nilai penjualan industri yang dinyatakan dalam bentuk persentase. Berikut hasil perhitungan pangsa pasar industri usaha mikro kecil menengah (umkm) kerupuk sagu di kecamatan kuantan tengah dan untuk rincian perhitungan nilai market share dapat dilihat pada tabel berikut :

Tabel 3. Perhitungan Market Share

\begin{tabular}{|c|c|c|c|}
\hline No & Nama Pegadang & Penjualan (Xi) & Market Share (\%) \\
\hline 1 & Air Mata & Rp.28.000.000 & 11,61 \\
\hline 2 & Nyonyok & Rp.26.000.000 & 10,78 \\
\hline 3 & Bujang Laisar & Rp.20.000.000 & 8,29 \\
\hline 4 & Noprianto & Rp.31.000.000 & 12,85 \\
\hline 5 & Rostina & Rp.30.000.000 & 12,43 \\
\hline 6 & Linda & Rp.24.000.000 & 9,95 \\
\hline 7 & Fitrianah & Rp.10.000.000 & 4,14 \\
\hline 8 & Basnah Riati & Rp.8.000.000 & 3,31 \\
\hline 9 & Asneti & Rp.18.000.000 & 7,46 \\
\hline 10 & Widia Jaya & Rp.10.160.000 & 4,21 \\
\hline 11 & Yusni & Rp.36.000.000 & 14,92 \\
\hline \multicolumn{2}{|r|}{ Total } & Rp.241.160.000 & $100 \%$ \\
\hline
\end{tabular}

\section{Concentration Ratio (CR4) Usaha Mikro Kecil Menengah Kerupuk Sagu Di Kecataman Kuantan Tengah.}

cr4 merupakan penjumlahan pangsa pasar empat perusahaan terbesar dari suatu wilayah pasar. Berikut hasil perhtiungan cr4 usaha mikro kecil menengah (umkm) kerupuk sagu di kecataman kuantan tengah dan untuk rincian perhitungn nilai cr4 dapat dilihat pada :

Tabel 4. : Perhitungan Konsentrasi Rastio 4 Perusahahan

\begin{tabular}{|c|l|c|c|}
\hline No & Nama Pegadang & Penjualan (Xi) & Market Share (\%) \\
\hline 1 & Air Mata & Rp.28.000.000 & 11,61 \\
\hline 2 & Nyonyok & Rp.26.000.000 & 10,78 \\
\hline 3 & Bujang Laisar & Rp.20.000.000 & 8,29 \\
\hline 4 & Noprianto & Rp.31.000.000 & 12,85 \\
\hline 5 & Rostina & Rp.30.000.000 & 12,43 \\
\hline
\end{tabular}




\begin{tabular}{|c|l|c|c|}
\hline 6 & Linda & Rp. 24.000 .000 & 9,95 \\
\hline 7 & Fitrianah & Rp. 10.000 .000 & 4,14 \\
\hline 8 & Basnah Riati & Rp. 8.000 .000 & 3,31 \\
\hline 9 & Asneti & Rp. 18.000 .000 & 7,46 \\
\hline 10 & Widia Jaya & Rp. 10.160 .000 & 4,21 \\
\hline 11 & Yusni & Rp. 36.000 .000 & 14,92 \\
\hline \multicolumn{2}{|c|}{ Total } & Rp.241.160.000 & $\mathbf{1 0 0 \%}$ \\
\hline
\end{tabular}

$\mathrm{CR} 4=\mathrm{MS} 1+\mathrm{MS} 2+\mathrm{MS} 3+\mathrm{MS} 4$

$=14,92+12,85+12,43+11,61$

$=51,81 \%$

Indeks Herfindahl - Hirsehman Usaha Mikro Kecil Menengah Kerupuk Sagu Di Kecamatan Kuantan Tengah.

IHH merupakan penjumlahan kuadrat pangsa pasar seluruh perusahaan dalam suatu industri. Berikut hasil perhitungan $I H H$ usaha mikro kecil menengah (umkm) kerupuk sagu di Kecamatan Kuantan Tengah dan untuk rincian perhitungan nilai $I H H$ dapat dilihat pada :

Tabel 5. : Penghitungan Indeks Herfiendahl Hirschman

\begin{tabular}{|c|l|c|c|c|}
\hline No & Nama Pegadang & Penjualan (Xi) & Market Share (\%) & $(\boldsymbol{M S})^{\mathbf{2}}$ \\
\hline 1 & Air Mata & Rp.28.000.000 & 11,61 & 124,54 \\
\hline 2 & Nyonyok & Rp.26.000.000 & 10,78 & 116,20 \\
\hline 3 & Bujang Laisar & Rp.20.000.000 & 8,29 & 68,72 \\
\hline 4 & Noprianto & Rp.31.000.000 & 12,85 & 168,12 \\
\hline 5 & Rostina & Rp.30.000.000 & 12,43 & 154,50 \\
\hline 6 & Linda & Rp.24.000.000 & 9,95 & 99 \\
\hline 7 & Fitrianah & Rp.10.000.000 & 4,14 & 17,13 \\
\hline 8 & Basnah Riati & Rp.8.000.000 & 3,31 & 10,95 \\
\hline 9 & Asneti & Rp.18.000.000 & 7,46 & 55,65 \\
\hline 10 & Widia Jaya & Rp.10.160.000 & 4,21 & 17,72 \\
\hline 11 & Yusni & Rp.36.000.000 & 14,92 & 226,60 \\
\hline \multicolumn{2}{r}{ Total } & Rp.241.160.000 & $\mathbf{1 0 0 \%}$ & $\mathbf{1 . 0 5 5 , 1 3}$ \\
\hline
\end{tabular}

\section{Hambatan Masuk Pasar}

Hambatan masuk pasar dapat diukur dengan rasio skala produksi dengan skala produksi minimum untuk mencapai efesiensi perusahaan (Minimum Efficiency Scale). MES merupakan uotput minimum yang dihasilkan perusahaan ketika perusahaan mencapai biaya produksi rata-rata terendahnya.

$$
\begin{gathered}
\text { MES }=\frac{\text { output perusahaan terbesar }}{\text { output total }} \times 100 \% \\
=\frac{36.000 .000}{241.160 .000} \times 100 \% \\
=14,92 \%
\end{gathered}
$$

\section{Perilaku Industri}

Dalam penelitian yang penulis lakukan maka di peroleh hasil bahwa usaha mikro kecil menengah (umkm) kerupuk sagu di kecamatan kuantan tengah memiliki beberapa strategi pemasaran yaitu :

Strategi Harga, di dalam industri kerupuk sagu yang ada di Kecamatan Kuantan Tengah memiliki keseragaman harga. Hal ini dikerenakan tidak ada satupun produsen yang dapat 
menguasai ataupun mendominasi pangsa pasar. Dalam menentukan harga biasanya setiap perusahaan hanya mendengar atau mencari informasi dari perusahaan lainnya, apabila ada satu perusahaan yang sedang menurunkan harga jual biasanya perusahaan lainnya juga akan mengikuti, baik itu dari perusahaan baru maupun perusahaan lainnya yang ada di dalam pasar. Maka hal inilah yang membuat keseragaman harga jual di industri kerupuk sagu yang ada di Kecamatan Kuantan Tengah.

Strategi produk, produk-produk yang dihasilkan oleh setiap industri hampir memilki corak yang hampir sama hanya saja ada beberapa penjual yang sudah memiliki merek produk didalam kemasannya yang betuliskan nama dan alamat perusahaan tersebut.

Strategi promosi, dalam segi promosi masing-masing penjual hanya dari penyampaian dari mulut kemulut saja serta seluruh pelaku industri memberikan jasa pengantaran kerupuk sagu langsung kepada konsumen, misalanya ke rumah makan, warung-warung kecil srta ke penjual langsung di pasar. Hal ini bertujuan untuk menjaga pengsa pasar dan kepuasan komsumen ataupun yang biasa mereka sebut langganan

\section{Kinerja Industri}

Table 6. Perhitungan Price Cost Margin

\begin{tabular}{|c|l|c|}
\hline No & Nama Pedagang & PCM $(\%)$ \\
\hline 1 & Air Mata & 37,14 \\
\hline 2 & Nyonyok & 36,15 \\
\hline 3 & Bujang Laisar & 32 \\
\hline 4 & Noprianto & 36,77 \\
\hline 5 & Rostina & 41 \\
\hline 6 & Linda & 45 \\
\hline 7 & Fitrianah & 26 \\
\hline 8 & Basnah Riati & 20 \\
\hline 9 & Asneti & 36,66 \\
\hline 10 & Widia Jaya & 25,59 \\
\hline 11 & Yusni Total & 30 \\
\hline \multicolumn{2}{|c|}{ Rata-Rata } & $\mathbf{3 2 4 , 3 1}$ \\
\hline \multicolumn{2}{|c|}{} \\
\hline
\end{tabular}

\section{a. Struktur Pasar}

Berdasarkan penelitian yang penulis lakukan menyatakan bahwa struktur pasar yang terbentuk dalam industri kerupuk sagu yang berada di Kecamatan Kuantan Tengah adalah pasar persaingan monopolistik . hal ini berdasarkan dari perhitungan CR4 yang diperoleh hasil sebesar $51,81 \%$ termasuk dalam $40<$ CR4 $<60$ sehingga tergolong kategori menengah kebawah. Dimana pangsa pasar tertinggi adalah sebesar 14,92\% dan terendah sebesar 3,31\%. Di dalam perhitungan $I H H$ termasuk dalam golongan $I H H<1500$ dimana tergolong perusahaan yang bersaing secara efektif. Kemudian setelah melakukan perhitungan terhadap skala minimum efisiensi (mes) untuk mengetahui besarnya hambatan pasar bagi pemain baru pada industri kerupuk sagu di Kecamatan Kuantan Tengah. Nilai $M E S$ yang didapat sebesar $14,92 \%$ yang memungkinkan pemain baru tergolong mudah untuk masuk kedalam pasar. Hal ini mengharuskan setiap perusahaan yang berada di dalam pasar harus siap bersaing dengan pemain baru yang akan mengancam pangsa pasar dari perusahan lama.

\section{b. Perilaku Industri}

Berdasar Penelitian deskriptif yang dilakukan dengan cara memberikan pertanyaan langsung kepada pelaku usaha kerupuk sagu yang ada di Kecamatan Kuantan Tengah . 
a. Strategi harga, di dalam industri kerupuk sagu yang ada di Kecamatan Kuantan Tengah memiliki keseragaman harga. Hal ini dikerenakan tidak ada satupun produsen yang dapat menguasai ataupun mendominasi pangsa pasar. Dalam menentukan harga biasanya setiap perusahaan hanya mendengar atau mencari informasi dari perusahaan lainnya, apabila ada satu perusahaan yang sedang menurunkan harga jual biasanya perusahaan lainnya juga akan mengikuti, baik itu dari perusahaan baru maupun perusahaan lainnya yang ada di dalam pasar. Maka hal inilah yang membuat keseragaman harga jual di industri kerupuk sagu yang ada di Kecamatan Kuantan Tengah.

b. Strategi produk, produk-produk yang dihasilkan oleh setiap industri hampir memilki corak yang hampir sama hanya saja ada bebrapa penjual yang sudah memiliki merek produk didalam kemasannya yang betuliskan nama dan alamat perusahaan tersebut.

c. Strategi promosi, dalam segi promosi masing-masing penjual hanya dari penyampaian dari mulut kemulut saja serta seluruh pelaku industri memberikan jasa pengantaran kerupuk sagu langsung kepada konsumen , misalanya ke rumah makan, warung-warung kecil serta ke penjual langsung di pasar. Hal ini bertujuan untuk menjaga pangsa pasar dan kepuasan komsumen ataupun yang biasa mereka sebut langganan.

\section{c. Kinerja industri}

Kinerja suatu industri sangat mencerminkan bagaimana kekuatan pasar dan efisiensi, tingkat keuntungan suatu perusahaan dapat dilihat dari kineja perusahaan melalui price cost margin $(\mathrm{pcm})$ yang digunakan untuk perkiraan keuntungan dari suatu industri.

Berdasarkan hasil penelitian, di peroleh rata-rata $P C M$ seluruh pelaku industri kerupuk sagu di kecamatan kuantan tengah sebesar 31,11 \%, PCM tertinggi senilai $45 \%$ dengan jumlah pangsa sebesar $9,95 \%$, sedangkan perusahaan dengan pangsa pasar tertinggi $14,92 \%$ nilai dari $P C M$ yang di dapatkan sebesar $30 \%$.

\section{PENUTUP}

\section{Kesimpulan}

Berdasarkan penjelasan dari pembahasan mengenai industri kecil kerupuk sagu di Kecamatan Kuantan Tengah maka dapat diambil kesimpulan sebagai berikut

\section{Struktur Pasar}

Berdasarkan penelitian yang penulis lakukan menyatakan bahwa struktur pasar yang terbentuk dalam industri kecil kerupuk sagu ini adalah pasar persaingan monopolistik yang sesuai dengan karakteristik pasar yang terbentuk dalam industri ini dan tingkat persaingan dalam industri ini adalah persaingan sangat efektif. Berdasarkan pada perhitungan $C R 4$ diperoleh nilai $51,81 \%$ yang tergolong kategori menengah kebawah dan nilai $I H H$ sebesar $1.055,13$ berada di $I H H \leq 1500$ yang termasuk dalam pasar yang tidak terkonsentrasi dimana tingkat persaingan pasar dalam industri ini sangat efektif dengan keseragaman harga yang dibuat oleh seluruh industri. Sementara itu tingkat hambatan masuk pasar pada industri kerupuk sagu ini diperoleh sebsar $14.92 \%$. Jadi dapat disumpulkan bahwa industri ini adalah pasar persaingan monopolistik dengan tingat persaingan yang sangat efektif. Jadi setiap industri harus siap menghadapi setiap ancaman dari setiap pesaingan maupun industri baru yang ingin masuk kedalam pasar karna persaingan di dalam industri cukup ketat dimana pangsa pasar terbesar hanya mencapai 14,92\%. Maka perusahaan lainnya maupun pendatang baru akan dengan mudah merebut pangsa pasarnya.

\section{Perilaku Pasar}

Berdasar penelitian deskriptif yang dilakukan dengan cara memberikan pertanyaan langsung 
kepada pelaku usaha kerupuk sagu yang ada di Kecamatan Kuantan Tengah .

a. Strategi harga

Di dalam industri kerupuk sagu yang ada di Kecamatan Kuantan Tengah memiliki keseragaman harga. Hal ini dikerenakan tidak ada satupun produsen yang dapat menguasai ataupun mendominasi pangsa pasar. Dalam menentukan harga biasanya setiap perusahaan hanya mendengar atau mencari informasi dari perusahaan lainnya, apabila ada satu perusahaan yang sedang menurunkan harga jual biasanya perusahaan lainnya juga akan mengikuti, baik itu dari perusahaan baru maupun perusahaan lainnya yang ada di dalam pasar. Maka hal inilah yang membuat keseragaman harga jual di industri kerupuk sagu yang ada di Kecamatan Kuantan Tengah. Di dalam penentuan harga barang ini sangat sesuai dengan karakteristik pasar monopolistik dimana kekuatan setiap pelaku industri hampr sama dan merata yang membuat kurangnya kekuatan mendominasi pasar oleh suatu industri dalam mengusai pasar maupun dalam penentuan atau penekanan harga. Sikap ini membuar kualitas produk dan promosi sangat mempengaruhi terhadap penjualan ataupun markser share dari suatu produsen kerupuk sagu yang ada di Kecamatan Kuantan Tengah.

b. Strategi produk

Produk-produk yang dihasilkan oleh setiap industri hampir memilki corak yang hampir sama hanya saja ada beberapa penjual yang sudah memiliki merek produk didalam kemasannya yang betuliskan nama dan alamat perusahaan tersebut dan untuk kemasan kerupuk sagu yang di jual mentah atausetengah jadi biasaya akan digunakan pelastik yang lebih modern atau lebih baik untuk menjaga kualitas dan keawetan kerupuk itu sendiri.

c. Strategi promosi

Dalam segi promosi masing-masing penjual hanya dari penyampaian dari mulut kemulut saja serta seluruh pelaku industri memberikan jasa pengantaran kerupuk sagu langsung kepada konsumen, misalanya ke rumah makan, warung-warung kecil serta ke penjual langsung di pasar. Hal ini bertujuan untuk menjaga pengsa pasar dan kepuasan komsumen ataupun yang biasa mereka sebut langganan.

\section{Kinerja Industri}

Kinerja dari industri kerupuk sagu di Kecamatan Kuantan Tengah dapat dilihat dari indikator Price Cost Margin (PCM). PCM merupakan salah satu indikator kinerja yang perkiraan dari keuntungan suatu industri. Berdasarkan hasil penelitian, di peroleh rata-rata $P C M$ seluruh pelaku industri kerupuk sagu di Kecamatan Kuantan Tengah sebesar 31,11 \%, PCM tertinggi senilai $45 \%$ dengan jumlah pangsa sebesar $9,95 \%$, sedangkan perusahaan dengan pangsa pasar tertinggi $14,92 \%$ nilai dari $P C M$ yang di dapatkan sebesar 30\%. Dilihat dari hasil perhitungan price cost margin dimana industri yang mendapat nilai teringgi merupakan industri yang tidak tergolong kedalam 4 perusahaan yang dianggap besar di dalam industri kerupuk sagu di Kecamatan Kuantan Tengah. Nilai price cost margin dari industri yang mendapatkan pangsa pasar teringgi hanya senilai $30 \%$ ataupun $15 \%$ lebih rendah dari industri yang mendapatkan nilai price cost margin tertinggi.

Jadi dapat disimpulkan bahwa tingkat keuntungan ataupun kualitas suatu perusahaan tidak dapat dilihat besarnya pangsa pasar yang didapatkan oleh suatu perusahaan. Pada hal ini, tidak menjamin suatu industri dengan pangsa besar akan memiliki tingkat keuntungan yang besar pula. Tingkat keuntungan suatu perusahaan dapat di pengaruhi oleh besarnya biaya produksi maupun upah dari tenaga kerja suatu perusahan yang beranekaragam.

\section{SARAN}

Berdasarkan kesimpulan dari penulis yang sudah dipaparkan maka ada beberapa saran dari penulis untuk industri kerupuk sagu yang ada di Kecamatan Kuantan Tengah: 
1. Para pelaku industri kerupuk sagu yang berada di Kecamatan Kuantan Tengah yang masih memproduksi dengan skala kecil diharapkan mampu memproduksi dengan skala besar. Hal ini akan lebih untuk meningkatkan pangsa pasar dengan tingginya permintaan konsumen, rata-rata para palaku usaha hanya melakukan produki sebanyak dua kali dalam satu minggu.

2. Untuk beberapa pelaku industri kerupuk sagu yang ada di Kecamatan Kuantan Tengah sebaik melakukan pencatatan keuangan yang bertujuan untuk mengetahui laba kotor ataupun laba bersih yang bisa dijadikan bahan evaluasi bagi industri tersebut.

3. Para pelaku industri industri kerupuk sagu yang ada di Kecamatan Kuantan Tengah masih banyak yang mengabaikan sistem promosi bagi produknya, kebanyakan hanya mengandalkan promisi dari mulut kemulut konsumen. Sebaiknya para pelaku usaha berani mengeluarkan biaya untuk lebih memprosikan produknya seperti memberikan nama produk maupun nomor hp didalam kemasanan sehingga komsumen bisa lebih mengenal produk dari masing-masing produsen.

\section{DAFTAR PUSTAKA}

Adi, M Kwartono. 2007. Analisis Usaha Kecil dan Menengah. Yogyakarta: Andi Offset.

Arikunto, S. 2010. Prosedur Penelitian Suatu Pendekatan Praktik. Jakarta: Rineka Cipta.

Arini, Dien, 2013. Analisis Kinerja Industri Kecil dan Menengah (IKM) Batik di Kota Pekalongan (pendekatan Structure-Conduct Performance) [skripsi]. Semarang: Universitas Diponogoro.

Baye, M. 2010. Managerial Economics And Business Strategy, Seventh Edition. Mcgraw-Hill Irwin. Singapura

Badan Pusat Statistika ( BPS) kabupaten kuantan singingi

Cila Apriande Dan Arief Daryanto. 2011.Analisis Struktur, Perilaku, Dan KinerjaIndustri Tepung Terigu Di Indonesia. Bogor: Institut Pertanian Bogor

Clark, Roger 2003. Industrial Economics. Blackwell Publishers, Oxford.

Dian Nova Yolanda. 2015. Structure-Conduct-Performance Industri Makanan Di Indonesia. Medan: Universitas Sumatera Utara

Dinas Koperasi perdagangan dan koperasi Kabupaten Kuantan Singingi, 2019. Kuantan Singingi

Etika LayungPrastiwi. 2012. Analisis Struktur, Perilaku Dan Kinerja Industri Minuman Ringan Di Indonesia. Bogor: Institut Pertanian Bogor

Hasibuan, N. 1994. Ekonomi Industri: Persaingan, Monopoli, dan Regulasi. LP3ES, Jakarta.

Jaya, W.K. 2001. Ekonomi Industri. Edisi Kedua. Yogyakarta: BPFE.

Lilik Yuliawati. 2017. Analisis Struktur, Perilaku, Dan Kinerja Industri Makanan Dan Minuman Di Indonesia. Jakarta: ASM BSI

Lincolin Arsyad, Stephanus Eri Kusuma. 2014 Ekonomika Industri Pendekatan Strukutur, Perilaku Dan Kinerja. Yogyakarta: UPP STIM YKPN

M Kwartono. 2007. Analisis Usaha Kecil Dan Menengah. Yogyakarta: Andi Offset

Muda Restu Pratama. 2017. Analisis Structure-Conduct-Performance (Scp) Pada Industri Kecil Dan Menengah Makanan Olahan Kota Pekanbaru (Studi Kasus Pada IKM Tahu di Kecamatan Payung Sekaki).Pekanbaru: Universitas Riau

Nabil Qudrotil Kholik. 2018. Analisis Struktur, Perilaku, Dan Kinerja Industri Minuman Ringan Di Indonesia Periode 2010-2014. Semarang: Universitas Diponegoro

Sutrisno Koswara. 2009. Pengolahan Aneka Kerupuk. Ebookpangan.com 
Sugiyono. 2005. Memahami Penelitian Kualitatif. Bandung: CV. Alfabeta

Tri Candra Natalia, Panji Deoranto dan Mas'ud Effendi. (2011). Analisis Struktur, Perilaku Dan Kinerja Pasar Pada Sentra Industri Bakpia Yogyakarta. Malang: Universitas Brawijaya

Undang-Undang Nomor 20 Tahun 2008 tentang UMKM

Wuryatno, T.A. 2007. Analisis Industri Batik Tulis di Kelurahan Kalimanyat dan Kelurahan Bandung Kota [Skripsi]. Semarang : Universitas Diponogoro. 